\title{
Sosiaalipedagogisen osaamisen tunnistaminen ja tunnustaminen varhaiskasvatuksessa
}

Kati Rintakorpi ja Johanna Holmikari

\section{Johdanto}

/arhaiskasvatuslaki (540/2018) ja Varhaiskasvatussuunnitelman perusteet eli VASU (2018), joka vastaa varhaiskasvatuksen valtakunnallista opetussuunnitelmaa, korostavat pedagogisesti painottunutta hoidon, kasvatuksen ja opetuksen kokonaisuutta varhaiskasvatuksessa. Ne nimeävät varhaiskasvatuksen opettajan pedagogiikan vastuuammattilaiseksi. Yliopistollisen opettajakoulutuksen saaneiden henkilöiden lisäksi varhaiskasvatuksessa työskentelee opettajina ammattikorkeakouluissa sosionomikoulutuksen saaneita henkilöitä. Varhaiskasvatuslain uudistuksen myötä ammattikorkeakouluista ei kuitenkaan enää tulevaisuudessa valmistu opettajaksi päteviä työntekijöitä, vaan valmistuvat opiskelijat työskentelevät varhaiskasvatuksen sosionomin nimikkeellä varhaiskasvatuksen opettajien ja varhaiskasvatuksen hoitajien rinnalla. "Mikä ihmeen varhaiskasvatuksen sosionomi?" kysyy moni.

Uusi varhaiskasvatuksen sosionomin tehtävä aiheuttaa tällä hetkellä paljon keskustelua ja epävarmuutta varhaiskasvatuksen kentällä ja opiskelijayhteisöissä. Lainmuutoksen jälkeen uusia varhaiskasvatuksen sosiono- 
min opetussuunnitelmia on rakennettu ammattikorkeakouluissa kansallisessa ja alueellisessa yhteistyössä ja yhteydessä kasvatus- ja yhteiskuntatieteelliseen tutkimukseen, Varhaiskasvatuksen koulutusten kehittämisfoorumin (2021) suosituksiin, varhaiskasvatuslakiin (540/2018) ja Varhaiskasvatussuunnitelman perusteisiin (2018). Lisäksi ammattikorkeakoulujen opetussuunnitelmatyössä on kartoitettu työnantajien eli kuntien ja varhaiskasvatusyritysten tarpeita ja käsityksiä varhaiskasvatuksen sosionomin tehtävänkuvasta käytännössä. Uusi tehtävänimike vaatii pohdintaa esimerkiksi sen suhteen, mitä osaamista varhaiskasvatuksen sosionomit tuovat hoidon, kasvatuksen ja opetuksen kokonaisuuteen, kun osaamisen pedagoginen painotus on opettajilla ja hoidollinen painotus varhaiskasvatuksen hoitajilla.

Pula pätevistä työntekijöistä on varhaiskasvatuksen arkea, ja huoli alan veto- ja pitovoimasta nousee yhteisiin keskusteluihin. Varhaiskasvatus tarvitsee alalle soveltuvia ja siellä viihtyviä koulutettuja osaajia, jotta laadukkaan varhaiskasvatuksen toteutuminen olisi mahdollista. Keskustelua ammattikorkeakoulumaailmasta käsin seuranneina ja ammattikorkeakoulujen opetussuunnitelmatyöskentelyyn osallistuneina sosiaalialan ja varhaiskasvatuksen asiantuntijoina olemme kiinnittäneet huomiota opettaja- ja sosionomikoulutusten väliseen jännitteeseen. Pelkäämme, että koulutusten ja ammattiryhmien välinen kilpailu voi haitata lapsen edun ja laadukkaan varhaiskasvatuksen toteutumista.

Uuden varhaiskasvatuslain synnyttämä uusi työnkuva edellyttää varhaiskasvatuksen sosionomien osaamisen määrittelemistä ja tekemistä tunnetuksi varhaiskasvatuksessa. Avaamme tässä puheenvuorossa varhaiskasvatuksen sosionomin osaamisen mahdollisia ulottuvuuksia hyödyntäen varhaiskasvatusta koskevia asiakirjoja. Kiinnitämme huomiomme erityisesti sosiaalipedagogiseen osaamiseen varhaiskasvatuksessa. Toivomme tarkastelun tukevan maassamme käynnissä olevaa prosessia, jotta sosionomien sosiaalipedagoginen osaaminen voitaisiin tunnistaa, ymmärtää ja tunnustaa olennaisena varhaiskasvatustyössä tarvittavana kompetenssina. Sosiaalipedagoginen osaaminen on tärkeää varhaiskasvatuksen laadun ja kehittämisen kannalta. Se vaatii henkilöstöltä sekä kasvatusettä yhteiskuntatieteellistä ymmärrystä. Käsityksemme mukaan varhaiskasvatuksen sosiaalipedagogisen luonteen tiedostaminen on välttämätöntä myös, jotta alan veto- ja pitovoimatekijät vahvistuvat ja moniammatillisen henkilöstön arvostus kasvaa (ks. Varhaiskasvatuksen koulutusten kehittämisfoorumi 2021). 


\section{Varhaiskasvatuksen opetussuunnitelma VASU}

Valtakunnalliset opetussuunnitelmat heijastavat yhteiskunnallisia, poliittisia, taloudellisia ja inhimillisiä arvoja. Ne tuovat esiin käsityksen siitä, mitä kussakin maassa pidetään arvokkaana esimerkiksi suhteessa lapsuuteen, oppimiseen ja hyvinvointiin. Opetussuunnitelmat esittävät opetukselle tavoitteita, joiden katsotaan syystä tai toisesta olevan tarkoituksenmukaisia uusien kansalaisten kasvattamisessa ja kouluttamisessa. (Alasuutari, Markström \& Vallberg-Roth 2014, 19.)

Suomalaisen varhaiskasvatuksen rakenteissa ja ohjauksessa on viime vuosina tapahtunut paljon muutoksia. Opetushallituksen vuonna 2018 julkaisema Varhaiskasvatussuunnitelman perusteet (VASU) on uuden varhaiskasvatuslain (540/2018) mukaisesti ensimmäinen varhaiskasvatuksen henkilöstöä velvoittava opetussuunnitelma Suomessa. VASU ja sen pohjalta laadittavat paikalliset ja lapsikohtaiset suunnitelmat pyrkivät vastaamaan yhteiskunnassa ja lasten kasvuympäristöissä tapahtuviin muutoksiin sekä ohjaavat uuden varhaiskasvatuslain (540/2018) toteuttamisessa. Yhtenäisten ja velvoittavien asiakirjojen tarkoituksena on luoda tasa-arvoiset edellytykset varhaiskasvatukseen osallistuvien lasten kokonaisvaltaiselle kasvulle, kehittymiselle ja oppimiselle (VASU 2018, 7).

Suomalainen varhaiskasvatus linkittyy pohjoismaiseen opetussuunnitelmatraditioon, jonka näkökulma on monien eri arvioiden mukaan sosiaalipedagoginen (Alasuutari ym. 2014; Bennett 2005; 2010; Starting Strong III 2012; Ringmose \& Kragh-Müller 2017). Sosiaalipedagogisessa opetussuunnitelmatraditiossa lapsi nähdään omien oikeuksiensa ja oman oppimisensa subjektina (Bennett 2010) ja VASU:n mukaan varhaiskasvatuksen tuleekin perustua lasten mielenkiinnon kohteisiin ja tarpeisiin (VASU 2018, 37). Sosiaalipedagogiselle opetussuunnitelmatraditiolle on tyypillistä, että lasten oppimiselle ei ole ennalta määrättyjä, yksityiskohtaisia tiedollisia tai taidollisia tavoitteita, vaan asetetut tavoitteet koskevat henkilöstöä ja toimintaa (Bennet 2010). Tämä näkökulma on keskeinen myös suomalaisessa varhaiskasvatuksen opetussuunnitelmassa (ks. VASU $2018,10)$. Sen mukaan varhaiskasvatusta tulee toteuttaa eheyttämällä laaja-alaisen osaamisen tavoitteita ja oppimisen alueita esimerkiksi leikkien, liikkuen, tutkien ja ilmaisten. Lapset ovat oman elämänsä ja oppimisensa toimijoita, eivät henkilöstön toiminnan kohteita. Lapset opettelevat, kokevat, toimivat ja osallistuvat kokonaisvaltaisella tavalla. VASU tuo esiin myös pyrkimyksen varhaiskasvatuksen toimintakulttuurin jatkuvaan kehittämiseen oppivana yhteisönä. (VASU 2018.) 
Keskeiset varhaiskasvatuksen tehtävät ja yleiset tavoitteet kuvataan VASU:ssa seuraavasti:

Varhaiskasvatus on yhteiskunnallinen palvelu, jolla on monia tehtäviä. Varhaiskasvatuksen tehtävä on edistää lasten kokonaisvaltaista kasvua, kehitystä ja oppimista yhteistyössä huoltajien kanssa. Varhaiskasvatus edistää lasten tasa-arvoa ja yhdenvertaisuutta ja ehkäisee syrjäytymistä. Varhaiskasvatuksessa opitut tiedot ja taidot vahvistavat lasten osallisuutta sekä aktiivista toimijuutta yhteiskunnassa. Lisäksi varhaiskasvatus tukee huoltajia kasvatustyössä sekä mahdollistaa heidän osallistumisensa työelämään tai opiskeluun. (VASU 2018, 14.)

Näin ollen varhaiskasvatuksessa yksilö-, yhteisö- ja yhteiskunnallinen taso kietoutuvat toisiinsa samalla tavoin kuin Nivalan ja Ryynäsen (2019, 28) esittämässä sosiaalipedagogisen näkökulman määritelmässä. Sen mukaan yksilötasolla ihmistä tarkastellaan ainutlaatuisena yksilönä, jonka osallisuuden ja toimijuuden tukeminen ja henkilökohtaisen potentiaalin toteutuminen on toiminnan ihanteena. Yhteisötasolla yksilön kasvun ajatellaan tapahtuvan yhteisössä ja yhteisöllisesti. Yhteisöjen kasvatuksellisia prosesseja tukemalla mahdollistetaan ihmisen kasvu yhteiselämään. Yhteiskunnallisella tasolla tunnistetaan kasvatuksen yhteiskunnalliset sidokset ja kasvatuksella tuetaan yksilön kiinnittymistä yhteiskuntaan huomioiden myös kriittinen ja reflektiivinen yhteiskunnan lukutaito, yhteiskunnallisuus ja toimijuus. (Nivala \& Ryynänen 2019, 28.)

Varhaiskasvatuslaki (540/2018) ja VASU (2018) korostavat kuitenkin sosiaalipedagogiikan sijaan (yleisen) pedagogiikan painottumista hoidon, kasvatuksen ja opetuksen kokonaisuudessa. VASU:n määritelmän mukaan pedagogiikka perustuu VASU:ssa kuvattuihin arvoihin, käsitykseen lapsesta, lapsuudesta ja oppimisesta. Pedagoginen toiminta määritellään erityisesti kasvatus- ja varhaiskasvatustieteeseen perustuvaksi suunnitelmalliseksi ja tavoitteelliseksi toiminnaksi, jonka tavoitteena on lasten hyvinvointi ja oppiminen. (VASU 2018, 21-22.)

Kasvatustieteen professori Kirsti Karilan $(2013,7)$ mukaan pedagogiikkakäsite on kulttuurisesti ja historiallisesti muuttuva. Varhaiskasvatusdokumenttien tarkastelu osoittaa, että tässä ajassa pedagogiikkakäsitteellä katetaan lähes koko varhaiskasvatuksen kenttä. Pedagogiikkaa on lapsiryhmien toiminnan suunnittelu, toiminnan suunnitelmallisuus ja ta- 
voitteellisuus sekä arviointi ja kehittäminen. Lisäksi pedagogiikkasateenvarjon alle mahtuu vuorovaikutus, institutionaalisuus, ammatillisuus, tiede- ja tutkimusperustaisuus, toiminnan havainnointi, dokumentointi ja toimintakulttuurin jatkuva arviointi ja kehittäminen, leikki, lasten aktiivisuus ja osallisuus sekä yhteistyö vanhempien ja muiden asiantuntijoiden kanssa (Alila \& Ukkonen-Mikkola 2018). Kun tästä kaikesta vastaa varhaiskasvatuslain mukaan varhaiskasvatuksen opettaja, osallistuu muu henkilöstö eli varhaiskasvatuksen sosionomit ja lastenhoitajat toiminnan suunnitteluun ja toteutukseen vailla erityistä vastuuasemaa (Varhaiskasvatuslaki 540/2018; VASU 2018, 18).

Opettajankoulutuksen näkökulma on pedagoginen ja se kiinnittyy kasvatustieteelliseen tutkimukseen. Sosionomikoulutus puolestaan perustuu sosiaalipedagogiseen lähestymistapaan ja kiinnittyy kasvatus- ja yhteiskuntatieteitä yhdistävään tutkimustraditioon (Arene 2017). Sosiaalipedagogiikkaa ei kuitenkaan suomalaisissa varhaiskasvatukseen liittyvissä asiakirjoissa, tutkimuksessa tai käytännöissä tunnisteta tai osata nimetä, vaikka kaikkien asiakirjojen lähestymistapa on pohjoismaisen tradition mukaisesti sosiaalipedagoginen. VASU:n mukaan toisia arvostava, koko yhteisöä osallistava ja luottamusta rakentava dialogi tulisi varhaiskasvatuksessa nähdä tärkeänä (VASU 2018, 29), mutta varhaiskasvatuksen sosionomille vaikuttaa olevan haasteellista löytää paikkaa varhaiskasvatuksen työyhteisössä, kun heidän koulutuksensa ja osaamisensa keskeinen kehys - sosiaalipedagogiikka - ei avaudu eri toimijoille suomalaisessa kasvatuskeskustelussa korkeakouluissa ja varhaiskasvatuksen kentällä. Mitä on sosiaalipedagoginen osaaminen, joka loistaa varhaiskasvatusasiakirjoissa poissaolollaan?

\section{Varhaiskasvatuksen tunnistamaton sosiaalipedagogisuus}

Suomalaisen varhaiskasvatuksen julkilausuttuja arvoja ovat lapsuuden itseisarvo, sivistykselliset arvot, yhdenvertaisuus, tasa-arvo ja moninaisuus sekä kestävä elämäntapa (Varhaiskasvatuksen arvioinnin perusteet ja suositukset 2018, 41-42; VASU 2018, 20-21). Nämä arvot on tunnistettavissa luonteeltaan selvästi sosiaalieettisiksi. Ne ohjaavat pohtimaan sosiaalipedagogisesti, miten kasvatuksessa voidaan toteuttaa ja edistää yhteiskunnan oikeudenmukaisuutta, tasa-arvoa, yhteistä hyötyä, yhteisvastuuta, solidaarisuutta, demokratiaa ja ihmisarvoa. (Ks. Hämäläinen \& Kurki 1997, 31.)

Varhaiskasvatussuunnitelman perusteiden edustaman oppimiskäsityksen mukaisesti lapset kasvavat, kehittyvät ja oppivat vuorovaikutukses- 
sa muiden ihmisten ja lähiympäristön kanssa. Kasvatus, opetus ja hoito muodostavat eheän kokonaisuuden (VASU 2018, 21-22). Sosiaalipedagogiikassa paneudutaan nimenomaan kasvatukseen ja kasvun prosesseihin sekä kasvun tukemiseen. Kasvatustieteellisestä näkökulmasta kasvatus on laaja-alaista toimintaa, jonka tehtävänä on sivistys- ja sosialisaatioprosessin sekä identiteetin rakentamisen tukeminen (Siljander 2002, 47-48). Sosiaalipedagogisesta viitekehyksestä kasvua tarkastelevat tutkijat puolestaan kiteyttävät, että kasvu on sivistymistä, sosialisaatiota ja identiteetin rakentumista ja kasvatus näiden prosessien tukemista (Nivala \& Ryynänen 2019 , 18). Kun varhaiskasvatuksen opetussuunnitelmaa tarkastellaan sekä pedagogisen että sosiaalipedagogisen ymmärryksen kautta, on selvää, että varhaiskasvatuksessa yhdistyy vahvasti yhteiskunta- ja kasvatustieteellinen näkökulma. Voidaan perustellusti kysyä, onko varhaiskasvatus tosiaan "pedagogisesti painottunut kasvatuksen, hoidon ja opetuksen kokonaisuus", kuten VASU:ssa $(2018,22)$ korostetaan, vai sittenkin sosiaalipedagogisesti painottunut.

Teoreettinen sosiaalipedagoginen keskustelu on tullut Suomeen verraten myöhään siihen nähden, että kasvatukseen on liitetty sosiaalinen ulottuvuus jo antiikin Kreikassa ja itse tieteenala on kehittynyt Saksassa 1800-luvulta alkaen. Sosiaalipedagogiikka on käsitteenä erittäin harvoin käytössä varhaiskasvatuksesta puhuttaessa. Sosiaalipedagogiikka mainitaan varhaiskasvatuslaissa ainoastaan varhaiskasvatuksen sosionomin kelpoisuuden määrittelyssä ja VASU:ssa sosiaalipedagogiikan käsitettä ei käytetä lainkaan. Myöskään tieteellisessä varhaiskasvatusta koskevassa suomalaisessa tutkimuksessa sosiaalipedagogiikan käsitettä ei juurikaan käytetä, vaikka paikkoja avautuisi esimerkiksi koulutuspoliittisissa ja osallisuus- ja toimijuustutkimuksissa.

Kun varhaiskasvatuksen sosiaalipedagogisuus tunnistetaan ja tunnustetaan, havaitaan, että pedagogiikan ammattilaisten - varhaiskasvatuksen opettajien - rinnalle tarvitaan kipeästi sosiaalipedagogisen osaamisen ammattilaisia ja arjen vastuunkantajia - varhaiskasvatuksen sosionomeja. Tällöin varhaiskasvatuksen arvopohjaa ja oppimiskäsitystä voidaan toteuttaa laajasti ja laadukkaasti toiminnan suunnittelussa, toteuttamisessa, arvioinnissa ja kehittämisessä. Laki ei kuitenkaan edellytä varhaiskasvatuksen sosionomin palkkaamista varhaiskasvatukseen, vaan hänet voidaan korvata varhaiskasvatuksen opettajalla. Joissakin kunnissa varhaiskasvatuksen sosionomeille ollaan luomassa uusia työnkuvia myös varhaiskasvatuksen ja perhetyön rajapinnoille. Näissä avauksissa sosionomin 
osaamisen tuominen kaikkien lasten ja työyhteisöjen ulottuville jokapäiväisessä varhaiskasvatuksessa jää kuitenkin valitettavasti puuttumaan. On selvää, että laatua toisi monipuolisesti osaava henkilöstö (ks. Nivala \& Rönkkö 2021). Miten voitaisiin muodostaa ammatillisen osaamisen vastuualueita rakentavasti, keskeisistä osaamisalueista käsin - tunnistaen ja tunnustaen sekä pedagogisen että sosiaalipedagogisen näkökulman vahvuudet ja rajat?

\section{Varhaiskasvatuksen sosionomin tunnustamaton sosiaalipedagoginen osaaminen}

Ammattikorkeakoulut nostavat sosiaalipedagogisen lähestymistavan esiin keskeisenä osana sosionomikoulutusta (Arene 2017) ja Sosiaalialan ammattikorkeakouluverkosto (2016) on hyväksynyt kuusi keskeistä sosionomin kompetenssia. Kompetenssikokonaisuudet koostuvat sosiaalialan eettisestä osaamisesta, asiakastyön osaamisesta, sosiaalialan palvelujärjestelmäosaamisesta, kriittisestä ja osallistavasta yhteiskuntaosaamisesta, tutkimuksellisesta kehittämis- ja innovaatio-osaamisesta sekä työyhteisö-, johtamis- ja yrittäjyysosaamisesta. Kun kompetensseja tarkastellaan VASU:n (2018) viitekehyksessä, on niistä löydettävissä osaamista, joka kiinnittyy vahvasti varhaiskasvatussuunnitelman perusteiden mukaiseen toimintaan ja yhdistyy myös keskeisesti sosiaalipedagogiseen työorientaatioon. Sosionomin osaamisen alueelle nousevat VASU:sta esimerkiksi yhdenvertaisuus ja tasa-arvo, monialainen yhteistyö ja verkosto-osaaminen, kasvun ja kehityksen tukeminen, moninaisuuden tukeminen, järjestelmäosaaminen ja osallisuuden tukeminen, tiimi- ja yhteisöosaaminen sekä kulttuurinen osaaminen (VASU 2018).

Varhaiskasvatuksen koulutusten kehittämisfoorumi (2021), johon kuuluu jäseniä kaikilta varhaiskasvatuksen henkilöstöä kouluttavilta tasoilta, on laatinut ehdotuksen varhaiskasvatuksen koulutusten kehittämisohjelmaksi vuosille 2021-2030. Kehittämisohjelmassa on kuvattu eri ammattiryhmien eriytyneen osaamisen profilit, joiden avulla on pyritty hahmottamaan yhteisen osaamisen lisäksi kunkin ammattiryhmän erityinen osaaminen. Sosiaalipedagogista osaamista ei kehittämisfoorumin ehdotuksessa nimetä, vaan siinä puhutaan pedagogisesta, hoidollisesta ja perhetyöhön liittyvästä erityisosaamisesta. Monet sosionomin osaamiseen ja sosiaalipedagogiseen teoriaperustaan juurtuvat alueet, kuten kulttuurisen moninaisuuden huomioiminen ja tukeminen, lasten ja perheiden osallisuutta tukeva vertaistoiminta ja yhteisöllisyys sekä verkostotoiminta tun- 
nistetaan kuuluvaksi opettajan pedagogiseen osaamiseen varhaiskasvatuksen sosionomin osaamisen sijaan.

Kehittämisfoorumin mukaan ehdotuksessa esitettyjä ammatillisia eriytyneen osaamisen profiileja voidaan pitää keskustelunavauksena, ja niiden työstämiseksi tarvitaan yhteisiä keskusteluja ja tutkimustietoa. Foorumin mukaan erityisen tärkeää on selkeyttää pedagogiikan, varhaiskasvatuksessa annettavan tuen ja moniammatillisen osaamisen tulkintoja. (Varhaiskasvatuksen koulutusten kehittämisfoorumi 2021, 86.) Kehittämisfoorumin ehdotus varhaiskasvatuksen sosionomin eriytyneestä osaamisesta on syntynyt osaamisprofilijaoston puheenjohtajan kompromissiehdotuksena, eivätkä kaikki osaamisprofiilijaoston jäsenet katsoneet voivansa sitoutua siihen kaikilta osin (Varhaiskasvatuksen koulutusten kehittämisfoorumi 2021, 83). Kun työryhmässä on keskusteltu pedagogisen vastuun jakamisesta varhaiskasvatuksen opettajien ja sosionomien kesken, on esiin nostettu, että pedagogiikka voi olla vain opettajan eriytyvää osaamista, koska opettajan koulutus painottuu pedagogiikkaan ja "geneerisiin opettamisen taitoihin". Näissä puheenvuoroissa on painotettu, että varhaiskasvatuksen opettajan koulutus on ainoa, joka suuntautuu kokonaisuudessaan pedagogiikkaan, jolloin sen täytyy olla opettajan eriytynyttä osaamista. (Varhaiskasvatuksen koulutusten kehittämisfoorumi 2021, 85.) Tämä Kehittämisfoorumin keskustelu vaikuttaisi kuitenkin olevan ristiriidassa VASU:n tekemän pedagogiikkamääritelmän kanssa. Edellä tekemiemme havaintojen perusteella VASU edustaa sosiaalipedagogista näkökulmaa, jonka erityisosaajaa ei löydy kehittämisfoorumin ehdotuksesta. Onkin syytä pohtia, mikä ammattiryhmä vastaa varhaiskasvatuksen demokraattisen, yhteiskunnallisen ja kokonaisvaltaisesti sivistävän toimintakulttuurin kehittämisestä oppivana yhteisönä. Millä ammattiryhmällä on verkosto-osaamista sekä teoreettisia ja käytännöllisiä menetelmiä yhteisöllisen työskentelyn suunnitteluun, toteuttamiseen, kehittämiseen ja arviointiin?

Kehittämisfoorumin asiakirjassa todetaan, että varhaiskasvatuksen koulutusta ja henkilöstöä koskeva tiedontuotanto on ollut hajanaista eikä säännöllistä tiedonkeruuta ole ollut (Varhaiskasvatuksen koulutusten kehittämisfoorumi 2021, 57). Tämä on vaikuttanut siihen, että henkilöstön koulutuksista tai kelpoisuuksista ei ole ollut käytössä luotettavaa tietoa. Varhaiskasvatuksen opettajuudelle asettuja vaatimuksia on tarkasteltu ainoastaan yliopistokoulutuksen näkökulmasta eikä ammattikorkeakoulutuksen tuottamaa sosionomin osaamista ei ole tutkittu juuri lain- 
kaan (Varhaiskasvatuksen koulutusten kehittämisfoorumi 2021, 61). Varhaiskasvatuksen koulutuksiin kohdistuvaa kansallista tutkimusta on kaiken kaikkiaan saatavilla niukasti (Alasuutari \& Raittila 2017; Varhaiskasvatuksen koulutusten kehittämisfoorumi 2021, 61). Tarkasteltaessa varhaiskasvatuksen koulutuksille asetettuja tavoitteita ja koulutusten rakentumista olisi kuitenkin aiheellista pystyä jäsentämään varhaiskasvatuksessa tarvittavia kompetensseja tutkimusperustaisesti (Varhaiskasvatuksen koulutusten kehittämisfoorumi 2021, 61).

\section{Sosionomin sosiaalipedagoginen osaaminen varhaiskasvatuksen rikkautena}

Varhaiskasvatuksen moniammatillisuuden kehittämisessä on keskeistä kirkastaa eri ammattiryhmien osaamista, jolloin jokaisen ammattiryhmän osaaminen tuodaan tietoisella tasolla osaksi moniammatillista yhteistyötä (Varhaiskasvatuksen koulutusten kehittämisfoorumi 2021, 87). Varhaiskasvatuksen sosionomi on täysin uusi, vasta muodostumassa ole työnkuva, jonka mahdollisuuksia ei kannattaisi hukata. Koska aikaisempi sosionomien ammattikorkeakoulutus on tähdännyt lastentarhanopettajan pätevyyteen, ei voida olettaa, että olisi jo olemassa jokin valmis tutkittu pohja varhaiskasvatuksen sosionomin osaamisen perustaksi. Sosiaalipedagogiikka on keskeinen osa sosionomitutkinnon teoreettista perustaa, ja se luo hyvän perustan varhaiskasvatuksen sosionomin osaamisen ja työnkuvan viitekehykseksi. Lisäksi se soveltuu saumattomasti varhaiskasvatuksen arvopohjaan, oppimiskäsitykseen, tavoitteisiin ja kokonaisvaltaiseen sekä moniammatilliseen lähestymistapaan. Tämä ei poista varhaiskasvatuksen kasvatustieteeseen perustuvaa pedagogisen osaamisen ja toteuttamisen vastuuta, joka on tunnistettu ja tunnustettu varhaiskasvatuksen opettajien eriytyväksi osaamiseksi.

Yhteenvetona toteamme, että näkemyksemme mukaan varhaiskasvatuksen sosionomin sosiaalipedagoginen osaaminen ulottuu kasvatuksen, hoidon ja opetuksen alueille sekä yhteisöpedagogiseen osaamiseen. Kasvatuksen, hoidon ja opetuksen osaaminen toteutuu tiiviisti lapsiryhmän arjessa, ja yhteisöpedagoginen osaaminen liittyy toimintakulttuurin kehittämiseen moniammatillisena oppivana yhteisönä. Sosiaalipedagoginen osaaminen mahdollistaa lasten oppimista, kasvua ja hyvinvointia tukevaa verkostoyhteistyötä sekä sosiokulttuuriseen innostamiseen (Kurki 2000) juurtuvaa toimintaa, jonka tarkoituksena varhaiskasvatuksessa on luoda ja tukea sosiaalisia verkostoja, lisätä kommunikaatiota ja suunnata 
toimintaa luovasti ja lapsilähtöisesti oppimisen, kasvun ja hyvinvoinnin tukemiseksi. Lisäksi ja edellisiin liittyen varhaiskasvatuksen sosionomin erityisosaamiseen kuuluu lasten ja vanhempien osallisuuden ja toimijuuden tukeminen sekä eriarvoistumisen, kiusaamisen ja syrjimisen ehkäiseminen. Tästä näkökulmasta käsin varhaiskasvatuksen sosionomi osaa tarkastella varhaiskasvatuksen sisällä olevia sekä yhteiskunnallisia ja kulttuurisia lasten elämään liittyviä rakenteita kriittisesti ja kehittää toimintatapoja, joiden avulla tuetaan integraatiota ja emansipaatiota varhaiskasvatuksessa. (Ks. Nivala \& Rönkkö 2021.)

Lopuksi painotamme, että kaikilla lapsilla tulee olla oikeus laadukkaaseen varhaiskasvatukseen, jossa monipuolisesti osaava henkilöstö puhaltaa yhteen hiileen keskinäisen kilpailun sijaan ja rakentaa yhdessä lasten ja huoltajien kanssa edellytyksiä oppimiselle ja hyvinvoinnille tänään ja huomenna. Tämä ajatus ei saa kadota, vaan varhaiskasvatuksen koulutuksia ja toimintakulttuuria on kehitettävä lapsen etu edellä. Etenkin opettajia ja sosionomeja kouluttavien korkeakoulujen on yhdistettävä osaamisensa ja voimansa rajat ylittävän tutkimuksen ja yhteistyön merkeissä.

\section{LÄHTEET}

Alasuutari, M., Markström, A.-M. \& Vallberg-Roth, A.-C. 2014. Assessment and documentation in early childhood education. London, New York: Routledge.

Alasuutari, M. \& Raittila, R. 2017. Varhaiskasvatustutkimuksen kaksi vuosikymmentä: tieteenalat, kysymyksenasettelut ja metodit. Kasvatus \& Aika 11 (3), 51-59.

Alila, K. \& Ukkonen-Mikkola, T. 2018. Käsiteanalyysistä varhaiskasvatuksen pedagogiikan määrittelyyn. Kasvatus 49 (1), 75-81.

Arene 2017. Ammattikorkeakoulujen rehtorineuvosto Arene ry:n työryhmän selvitys sosiaalialan tilanteesta ja kehityksestä. Helsinki: Ammattikorkeakoulujen rehtorineuvosto Arene ry. Saatavissa http://www.arene.fi/wpcontent/uploads/Raportit/2018/ arene_sosionomiselvitys_pitka_raportti_fin.pdf?_t=1526901428 (haettu 3.5.2021).

Bennett, J. 2005. The OECD Thematic Review of Early Childhood Education and Care Policy. Learning with Other Countries: International Models of Early Education and Care. London: Daycare Trust.

Bennett, J. 2010. Pedagogy in early childhood services with special reference to Nordic approaches. Psychological Science and Education 3, 16-21.

Hämäläinen, J. \& Kurki, L. 1997. Sosiaalipedagogiikka. Helsinki: WSOY

Karila, K. 2013. Ammattilaissukupolvet varhaiskasvatuksen pedagogiikan toteuttajina ja kehittäjinä. Teoksessa K. Karila \& L. Lipponen (toim.) Varhaiskasvatuksen pedagogiikka. Tampere: Vastapaino, 9-29. 
Kurki, L. 2000. Sosiokulttuurinen innostaminen. Tampere: Osuuskunta Vastapaino.

Nivala, E. \& Ryynänen, S. 2019. Sosiaalipedagogiikka. Kohti inhimillisempää yhteiskuntaa. Helsinki: Gaudeamus.

Nivala, E. \& Rönkkö, S. 2021. Varhaiskasvatuksen sosionomin asiantuntijuus ja sosiaalipedagoginen osaaminen. Teoksessa E. Fonsén, M. Koivula, R. Korhonen \& T. Ukkonen-Mikkola (toim.) Varhaiskasvatuksen asiantuntijat. Yhteistyössä eteenpäin. Oulu: Suomen varhaiskasvatus ry, 127-146

Ringmose, C. \& Kragh-Müller, G. 2017. Nordic social pedagogical approach to early years. Cham: Springer.

Siljander, P. 2002. Systemaattinen johdatus kasvatustieteeseen. Helsinki: Otava.

Sosiaalialan ammattikorkeakouluverkosto 2016. Sosiaalialan ammattikorkeakoulutuksen osaamisvaatimukset eli kompetenssit. Hyväksytty sosiaalialan AMK-verkoston verkostokokouksessa Kuopiossa 29.4.2016. Saatavissa https://www.diak.fi/ opiskelu/opiskelijan-polku/opintojen-suorittaminen/arviointi/osaamisvaatimukset-sosionomi/\#366283d6 (haettu 20.5.2021).

Starting Strong III 2012. A Quality Toolbox for Early Childhood Education and Care. Paris: OECD Publishing.

Varhaiskasvatuksen arvioinnin perusteet ja suositukset 2018. Varhaiskasvatuksen laadun arviointia ohjaavia arvoja. Julkaisut 24:2018. Helsinki: Kansallinen koulutuksen arviointikeskus.

Varhaiskasvatuksen koulutusten kehittämisfoorumi 2021. Opetus- ja kulttuuriministeriön julkaisuja 2021:3. Varhaiskasvatuksen koulutusten kehittämisohjelma 20212030. Helsinki: Opetus- ja kulttuuriministeriö, 57-59. Saatavissa https://julkaisut. valtioneuvosto.fi/bitstream/handle/10024/162662/OKM_2021_3.pdf?sequence=1\&isAllowed =y (haettu 3.5.2021).

Varhaiskasvatuslaki 540/2018.

Varhaiskasvatussuunnitelman perusteet (VASU) 2018. Määräykset ja ohjeet 2018:3a. Helsinki: Opetushallitus. Saatavissa https://www.oph.fi/sites/default/files/documents/varhaiskasvatussuunnitelman_perusteet.pdf (haettu 20.5.2021). 
252 - Sosiaalipedagoginen aikakauskirja, vuosikirja 2021, vol. 22 